\title{
COMPARATIVE ANALYSIS OF WATER RESOURCES MANAGEMENT SERVICE COSTS FOR DELTA BRANTAS IRRIGATION AREA
}

\author{
Widhie Arzy Restuanti, Nadjadji Anwar and Retno Indryani \\ Department of Civil Engineering, Sepuluh Nopember Institute of Technology, Surabaya, Indonesia \\ E-Mail: widhie_acik@yahoo.com
}

\begin{abstract}
A proper fuction of irrigation system needs sustainable water resource management, supported by Water Resources Management Service Costs (BJPSDA). BJPSDA is a partial reimbursement of the cost required for water resource management activities, especially for operation and maintenance activities, must be calculated and set by water resources management. There are two methods that are used to calculate BJPSDA, which is BJPSDA in accordance with the Regulation of the Minister of Public Works and Public Housing No. 18/PRT/M/2015 and BJPSDA using basic service fee by considering the quality of service and value of economic benefits modelling. This study was conducted by comparing two BJPSDA methods in the Delta Brantas Irrigation Area and will be analyzed descriptively. BJPSDA of irrigation in accordance with Regulation of the Minister of Public Works and Public Housing No. 18/PRT/M/2015 is Rp. $255,-/ \mathrm{m}^{3}$, as cost recovery.. BJPSDA of irrigation value using basic service fee by considering the quality of service and value of economic benefit modelling amounted Rp. 338,-/ $\mathrm{m}^{3}$, calculated from basic service fee amounted Rp. 177,-/ $\mathrm{m}^{3}$, added with NME for agriculture water in Delta Brantas Irrigation Area amounted Rp. 161/m², as a water value.
\end{abstract}

Keywords : water resources management service cost, value of economic benefit, BJPSDA of irrigation, cost recovery, water value, Delta Brantas Irrigation Area

\section{INTRODUCTION}

To maintain the sustainability of the irrigation system, it necessary to manage the water resources. To support the water resources management activities, needs water resources management service costs. Funds provision for water resources management service still provided by the government. Government limited funds led to shortages in fulfilling the needs of water resource management service costs. To cover the cost deficits deviation of the management, obtained from the BJPSDA reception. BJPSDA is the funds of that collected and receive by the water resource management from the users of its utilization.

BJPSDA was not a payment for the water price, but as compensation for water resource management service cost. Water resource management service fees intended as the istrument so the society more efficient for water usage and grow the society participation due to preserving and maintaining the water resource or the water resource infrastructure.

Delta Brantas Irrigation Area is one of the largest irrigation area in East Java, with a total covering irrigated area 21,984 Ha. Delta Brantas Irrigation Area irrigated by two irrigation network, Mangetan Kanal irrigation network with extensive 11,390 $\mathrm{Ha}$ and Porong Kanal irrigation network with extensive 10,594 Ha. Delta Brantas hydrologicaly located in Brantas River Basin and Brantas Watershed. Brantas River Basin are the national strategical river basin and the water resource management has become the authority of the Central Government under the Brantas River Basin Agency.

BJPSDA must be calculated and set by water resources management, so it necessary need calculation and determination analysis of BJPSDA of irrigation. BJPSDA is calculated by the principle of cost recovery of operation and maintenance of water resources management.

There are two methods of BJPSDA calculation, BJPSDA calculation in accordance with the Regulation of the Minister of Public Works and Public Housing No. 18/PRT/M/2015 ${ }^{[1]}$ and BJPSDA using basic service fee by considering the quality of service and value of economic benefits modelling ${ }^{[2]}$. This study was conducted by comparing the two BJPSDA methods for irrigation in the Delta Brantas Irrigation Area and will be analyzed descriptively.

\section{LITERATURE REVIEW Irrigation}

In the Regulation of the Minister of Public Works and Public Housing No. 30/PRT/M/2015 ${ }^{[3]}$ about the Irrigation System Development and Management, irrigation is a business of irrigation water provision, arrangement, and disposal to support the agriculture type of surface irrigation, swamp irrigation, underground water irrigation, pump irrigation and fishpond irrigation. Irrigation serves to support the agriculture productivity to increase the agricultural production in order to national food secure and society welfare, specially farmers, which realized through the sustainability of irrigation system. Irrigation system includes irrigation infrastucture, irrigation water, irrigation management, institutional of irrigation management and human resources. Irrigation infrastructure consisting buildings and aquaducts with its complementary reffered as irrigation network ${ }^{[4]}$.

Irrigation management regulated in Regulation of the Ministry of Public Works and Public Housing No. 30/PRT/M/2015 $5^{[3]}$ about the Irrigation System Development and Management, that the Minister have the authority and responsibility in maintaining the effectiveness, efficiency, and execution diciplines of development and management of primary irrigation system and secondary in irrigation area which covers more than 3,000 Ha, or in the irrigation area across the province, irrigation area across the nation, and irrigation area nationally strategic.

In the implementation of the operation and irrigation network routine maintenance, conducted by City Department of Public Works through Co-Administration of Operation and Maintenance (TP-OP) from the central government. Assistance are assignment of the central government to regional or village to perform certain tasks 
along with financing, infrastructures and facilities and human resources with obligation to report its implementation, and accountable to the central government by using the funds that provided by the Ministry of Public Works and Public Housing in the form of Special Allocation Funds, deconcentration funds and task fund ${ }^{[3]}$.

\section{Water Resource Management Costs}

To preserve and maintain the availability of the water required water resources management. Water resource management activities consist of activities to plan, implement, monitor and evaluate the implementation of the water resources conservation, water resources utilization, and control of water destructive force. Cost to conduct water resources management are necessary called cost of water resources management.

Based on the Regulation of the Minister of Public Works and Public Housing No. 18/PRT/M/2015, that the funding of water resources management activities was assigned based on the real needs for water resources management. The financing for the water resources management activities are covering for information system cost, planning cost, construction cost, operational and maintenance cost, monitoring, evaluation and society empowerment cost, and operational costs of river basin management office ${ }^{[1]}$.

\section{Water Resource Management Service Costs (BJPSDA)}

Financing of the water resources management activitiesis needed to support the implementation of water resources management in a sustainable manner. The beneficiaries of water services in principle obliged to bear the management costs in accordance with gained benefits through Water Resources Management Service Costs (BJPSDA). BJPSDA is a partial reimbursement of the cost that required for the water resource management activity, especially for operational and maintenance. Charging of water resources management service is intended as an instrument, so the society economize the water use and to cultivate the community participation in protecting and maintaining the water resources or water resources infrastructure $^{[1][5]}$.

There are two method that can be use for BJPSDA irrigation calculation, which is :

1. The amount of BJPSDA calculated based on the Regulation of the Minister of Public Works and Public Housing No. 18/PRT/M/2015 ${ }^{[1][5]}$, using the following formula :

$$
\mathrm{BJPSDA}=\frac{\text { (water resource management cost } x \% \text { Value of economic benefit) }}{\text { Area of agricultural }}
$$

Where :

a. Amount of the water resource management cost, is the total amount of water resources management financing is assigned based on the real needs for water resources management in each river basin. Water resource Management costs consists of information systems cost, planning cost, construction cost, operational and maintenance cost, monitoring, evaluation and society empowerment cost, and operational costs of river basin management office. The required amount of water resource management costs is calculated in rupiah (Rp) units.

b. Value of economic benefit (NME), is a benefit derived from the use of water in the river basin for agricultural activities, the calculation obtained from agricultural products profits (total income minus total production costs). Value of economic benefit used in this calculation is the agricultural value of economic percent from value of economic benefit of river basin. Value of economic benefit defined in terms of percent (\%).

c. The agricultural area is the area that used to do agricultural business in hectare area (Ha) units.

d. The BJPSDA value calculation for agricultural business, defined in rupiah/hectare $(\mathrm{Rp} / \mathrm{Ha})$ units.

2. The ammount of Water Resources Management Fees (BJPSDA) irrigation based on the basic service fee by considering the quality of service and value of economic benefits modelling ${ }^{[2]}$, using formula :

\section{BJPSDA = (basic service fee $x$ quality of service factor) + value of economic benefit}

Where :

a. Basic service fee is the total cost that generated from the average of water resource management costs in five years, devided with the amount of water use from the river basin. Basic service costs are calculated in rupiah/cubic meter $\left(\mathrm{Rp} / \mathrm{m}^{3}\right)$ units.

b. Quality of service factor is the service quality level that give by the water resource management, covering conflict condition, service levels, and water quality. Service quality factor is calculated in terms of percent (\%).

c. Value of economic benefit (NME) is a benefit derived from the use of water in the river basin for agricultural activities, the calculation of profits obtained from agricultural products (total income minus total production costs) multiplied by water contribution factor for agriculture. NME is calculated in Rupiah/cubic meter $\left(\mathrm{Rp} / \mathrm{m}^{3}\right)$ units.

d. BJPSDA of irrigation, determined in Rupiah/cubic meter $\left(\mathrm{Rp} / \mathrm{m}^{3}\right)$ units.

\section{METHODS}

Object of this study is Delta Brantas Irrigation Area. Delta Brantas Irrigation Area is located in the district of Sidoarjo. Delta Brantas Irrigation Area has an area of 21,984 Ha covering 18 sub districts in Sidoarjo. Delta Brantas Irrigation Area get a supply of irrigation water from the Lengkong Dam which is administratively located in the Miriprowo village, Tarik district, Sidoarjo. Delta Brantas Irrigation Area is divided into two Irrigation Network that originated from a Kepajaran devider structure of Lengkong Dam, which Porong Kanal irrigation network with an irrigation area of 10,594 Ha and Mangetan Kanal irrigation network with an irrigation area of $11,390 \mathrm{Ha}$.

The data used is secondary data obtained through data collection. Data collection through literature studies conducted to get the theoretical basis supporting research creating the data analysis. 
This study was was conducted by comparing the two BJPSDA methods for irrigation in the Delta Brantas Irrigation Area and will be analyzed descriptively. Descriptive analysis was used to calculate BJPSDA irrigation based on the Regulation of the Ministry of Public Works and Public Housing No. 18/PRT/M/2015, calculate BJPSDA irrigation using basic service fee by considering the quality of service and value of economic benefits modelling, and analyze the differences in the results of both methods of calculation.

Process study is shown in the figure below :

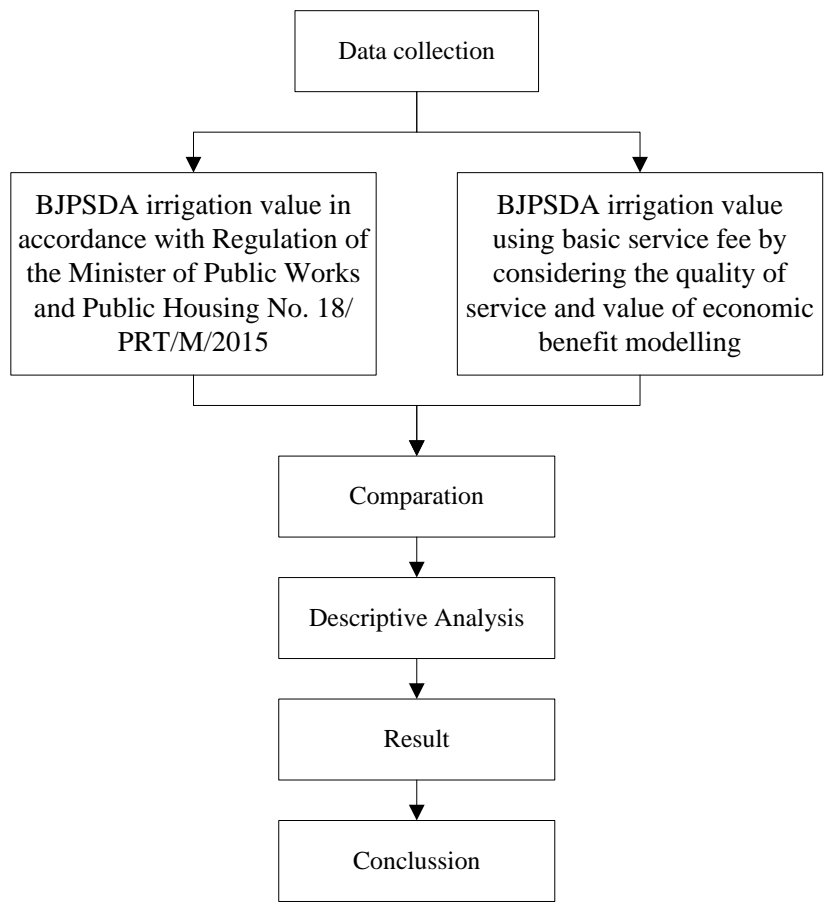

Figure-1. Process Study

\section{RESULTS AND DISCUSSIONS}

A. BJPSDA of Irrigation Based on the Regulation of the Minister of Public Works and Public Housing No. 18/PRT/M/2015

The components for calculating BJPSDA of irrigation based on the Regulation of the Ministry of Public Works and Public Housing No. 18/PRT/ M/2015 is the cost of water resource management, value of economic benefit, and the volume or the production result.

\section{Brantas River Basin Water Resources Management Costs}

Water resource management costs are the costs that required for the management of water resources, and calculated based on real needs. Water resource management costs consisting of :

1. Information system cost

2. Planning Cost

3. Construction cost

4. Operational and maintenance cost

5. Monitoring, evaluation, and society empowerment cost

6. Operational costs of river basin management office Summary for water resource management cost of Brantas River Basin for 1 year is :
Table-1. Water Resource Management Cost of Brantas River Basin

\begin{tabular}{|c|l|r|}
\hline No. & \multicolumn{1}{|c|}{ Type of Cost } & \multicolumn{1}{c|}{ Amount [Rp] } \\
\hline 1 & Information system cost & $142.472 .943 .000,00$ \\
\hline 2 & Planning cost & $75.932 .772 .000,00$ \\
\hline 3 & Construction cost & $340.320 .057 .227,00$ \\
\hline 4 & Operational and maintenance cost & $578.169 .185 .684,73$ \\
\hline 5 & $\begin{array}{l}\text { Monitoring, evaluation, and society } \\
\text { empowerment cost }\end{array}$ & $243.555 .155 .000,00$ \\
\hline 6 & $\begin{array}{l}\text { Operational costs of river basin management } \\
\text { office }\end{array}$ & $32.799 .241 .000,00$ \\
\hline & \multicolumn{2}{|c|}{ Total } \\
\hline
\end{tabular}

Construction costs are calculated only for construction that have a direct benefit to the water resources conservation. Construction costs were not calculated is the construction cost are an investment, wich are the construction of dams, ponds, irrigation building, raw water facilities, flushing, waste water management, river bank reinforcement and beach protection structure.

Operational and maintenance costs of water resources structure is calculated by empirical methods. This empirical method used the value of a certain percentage from infrastructure assets at the time its constructed and useful lives as follows :

1. Operational cost $=0.9 \%$ from the assets value

2. Maintanance Cost :

a. Assets useful life $<5$ years $=0.60 \%$ from the assets value

b. Assets useful life $5-25$ years $=1.30 \%$ from the assets value

c. Assets useful life $>25$ years $=1.90 \%$ from the assets value

For the operational and maintenance cost of river and existing river structure and the the irrigation network is still calculated based on real needs.

\section{Value of Economic Benefit (NME)}

Value of economic benefit (NME) is a benefit or advantage derived from the use of water in a river basin. The use of water that calculated the value of economic benefit are :

1. Value of economic benefit for agricultural, was the agricultural results profits, calculated from the agricultural reception of paddy, corn, and soybean, deducted by production costs.

2. Value of economic benefit for flood control, is calculated by multiplying the agricultural NME with an area of paddy fields that can be secured from flooding or free from flooding. Value of economic benefit for flood control $=$ value of economic benefit for agricultural.

3. Value of economic benefit for flushing activity, calculated from the volume of water used for flushing activities multiplied by the price of raw water for flushing activities.

4. Value of economic benefit for drinking water industry (PDAM), calculated by gross earned income approach each PDAM as the drinking water business.

5. Value of economic benefit for Hydroelectric plants (PLTA), obtained from gross income, which multiplying by amount of electricity generated by the provider selling rates for the State Electricity Company (PLN). 
6. Value of economic benefit for Industrial, the value of water contribution from industries that takes the water in the Brantas River Basin.

Value of economic benefit summary for water users in Brantas River Basin as follow :

Table-2. Value of Economic Benefit in Bantas River Basin

\begin{tabular}{|c|c|c|c|}
\hline No. & Descriptiom & Unit & Value \\
\hline 1 & $\begin{array}{l}\text { Unit price value of benefit } \\
\text { a. PLTA } \\
\text { b. PDAM } \\
\text { c. Industry } \\
\text { d. Agriculture } \\
\text { e. Flood Control } \\
\text { f. Flushing activity }\end{array}$ & $\begin{array}{c}\mathrm{Rp} / \mathrm{kWh} \\
\mathrm{Rp} / \mathrm{m} 3 \\
\mathrm{Rp} / \mathrm{m} 3 \\
\mathrm{Rp} / \mathrm{Ha} \\
\mathrm{Rp} / \mathrm{Ha} \\
\mathrm{Rp} / \mathrm{m} 3\end{array}$ & $\begin{array}{r}883 \\
2.169 \\
1.980 \\
7.388 .794 \\
7.388 .794 \\
522\end{array}$ \\
\hline 2 & $\begin{array}{l}\text { Volume or production } \\
\text { a. PLTA } \\
\text { b. PDAM } \\
\text { c. Industry } \\
\text { d. Agriculture } \\
\text { e. Flood Control } \\
\text { f. Flushing activity }\end{array}$ & $\begin{array}{c}\text { kWh } \\
\text { m3 } \\
\text { m3 } \\
\text { Ha harvested } \\
\text { Ha } \\
\text { m3 }\end{array}$ & $\begin{array}{r}993.886 .961 \\
409.952 .736 \\
263.118 .540 \\
1.078 .589 \\
317.131 \\
116.640 .000\end{array}$ \\
\hline 3 & $\begin{array}{l}\text { Value of Economic Benefit (NME } \\
\text { a. PLTA } \\
\text { b. PDAM } \\
\text { c. Industry } \\
\text { d. Agriculture } \\
\text { e. Flood Control } \\
\text { f. Flushing activity } \\
\text { Total }\end{array}$ & $\begin{array}{l}\mathrm{Rp} \\
\mathrm{Rp} \\
\mathrm{Rp} \\
\mathrm{Rp} \\
\mathrm{Rp} \\
\mathrm{Rp} \\
\mathrm{Rp}\end{array}$ & \begin{tabular}{r|}
877.204 .600 .461 \\
889.358 .960 .478 \\
521.059 .256 .000 \\
7.969 .471 .157 .156 \\
2.343 .215 .528 .511 \\
60.886 .080 .000 \\
12.661 .195 .582 .606
\end{tabular} \\
\hline 4 & $\begin{array}{l}\text { Percentage of Value of Economic } \\
\text { a. PLTA } \\
\text { b. PDAM } \\
\text { c. Industry } \\
\text { d. Agriculture } \\
\text { e. Flood Control } \\
\text { f. Flushing activity } \\
\text { Total }\end{array}$ & $\begin{array}{r}\text { c Benefit } \\
\% \\
\% \\
\% \\
\% \\
\% \\
\%\end{array}$ & \begin{tabular}{r|}
$6,93 \%$ \\
$7,02 \%$ \\
$4,12 \%$ \\
$62,94 \%$ \\
$18,51 \%$ \\
$0,48 \%$ \\
$100,00 \%$
\end{tabular} \\
\hline
\end{tabular}

\section{BJPSDA of Irrigation}

To calculate the BJPSDA of irrigation, performed by multiplying the percentage of the value of economic benefits with water resources management cost, and then divided by the volume or the production result.

The total cost for water resources management activities in Brantas River Basin is Rp. 1.413.249.353.912,-, then BJPSDA can be calculated as follow :

$$
\begin{aligned}
\text { BJPSDA } & =\frac{\text { water resource management cost } \mathrm{x} \% \mathrm{NME}}{\text { area of agricultural }} \\
& =\frac{\text { Rp.1.413.249.353.912,- } \mathrm{x} 62,94 \%}{1.078 .589 \mathrm{Ha}} \\
& =\text { Rp. } 824.741,-\mathrm{Ha}
\end{aligned}
$$

From calculation above, BJPSDA of irrigation unit value for Delta Brantas Irrigation Area is Rp. 824.741,-/Ha. BJPSDA of irrigation value for Delta Brantas Irrigation Area equal to the value of BJPSDA of irrigation in Brantas River Basin.

Conversion of BJPSDA if performed for water usage is as follows:

BJPSDA per water usage $=\frac{\text { BJPSDA }}{\text { water usage }: \text { harvested area }}$

$$
\begin{aligned}
& =\frac{\text { BJPSDA }}{\text { water usage }: \text { harvested area }} \\
& =\text { Rp. } 255,-/ \mathrm{m}^{3}
\end{aligned}
$$

From calculation above, BJPSDA of irrigation unit value for Delta Brantas Irrigation Area is Rp. 255,- $/ \mathrm{m}^{3}$.

\section{B. BJPSDA of Irrigation Based on the Basic Service Fee by Considering the Quality of Service and Value of Economic Benefits Modelling}

The components for calculating BJPSDA of irrigation based on the basic service fee by considering the quality of service and value of economic benefits modelling is the basic services cost, quality service factor, and value of economic benefit.

\section{Basic Service Fee}

Basic service fee is calculated from water resource management costs are the costs that required for the management of water resources and devided by the water used in the Brantas River Basin. The water usage in Brantas River Basin can be seen as follow :

Table-3. Water Usage in Brantas River Basin

\begin{tabular}{|r|l|r|}
\hline No. & \multicolumn{1}{|c|}{ Usage } & \multicolumn{1}{c|}{$\begin{array}{c}\text { Total } \\
\text { (m3/year) }\end{array}$} \\
\hline 1 & Agriculture & 3.492 .648 .792 \\
\hline 2 & Flushing activity & 116.640 .000 \\
\hline 3 & Flood control & 1.026 .922 .455 \\
\hline 4 & PDAM & 409.952 .736 \\
\hline 5 & PLTA & 88.841 .324 \\
\hline 6 & Industry Total & 263.118 .540 \\
\hline & 2 & 5.398 .123 .847 \\
\hline
\end{tabular}

The total cost for water resources management activities in Brantas River Basin is Rp. 1.413.249.353.912,-, then basic service fee can be calculated as follow :

$$
\begin{aligned}
\text { Basic service fee } & =\frac{\text { Rp. } 1.413 .249 .353 .912,-}{5.398 .123 .847 \mathrm{~m} 3} \\
& =\text { Rp. } 262,-/ \mathrm{m}^{3}
\end{aligned}
$$

\section{Quality of Service Factor}

The quality of service factor is the level of manager's ability to serve the water users. The affecting factor to the quality of water resource management services is conflict conditions, level of service, and water quality $^{[2]}$.

a. Conflict conditions, can be reflected on the fulfillment of the irrigation water ( $\mathrm{k}$ factor). The amount of water availability to flow through Delta Brantas Irrigation Area is $17,23 \mathrm{~m}^{3} / \mathrm{sec}$, the water required in accordance with cropping pattern is $21,08 \mathrm{~m}^{3} / \mathrm{sec}$. Then the value of $\mathrm{k}$ factors is $81,74 \%$. $\mathrm{K}$ factor value was included in index performance value of irrigation network.

b. The level of service, indicated by the index performance value of the irrigation network. The index performance value of Delta Brantas Irrigation Area is $67.66 \%$.

c. Water quality, water quality in the Brantas River Basin included in the category of class 2 and are in accordance with use as water for agriculture. So the value of the water quality factor is $100 \%$ 
From these three values, the value for quality of service factor for Delta Brantas Irrigation Area was $67,66 \%$ (67,66\% multiplied by $100 \%)$.

\section{Value of Economic Benefit (NME)}

Value of economic benefit of agriculture in Delta Brantas Irrigation Area was the agricultural results profits, calculated from the agricultural reception reduced by production costs.

Agricultural value of economic benefit calculation for Delta Brantas Irrigation Area can be seen as follows :

Table-4. Agricultural Value of Economic Benefit for Delta Brantas Irrigation Area

\begin{tabular}{|c|l|c|r|r|r|}
\hline No. & \multicolumn{1}{|c|}{ Uraian } & Unit & \multicolumn{1}{c|}{ Paddy } & \multicolumn{1}{c|}{ Corn } & \multicolumn{1}{c|}{ Soybean } \\
\hline 1 & Rice field area & $\mathrm{Ha}$ & 21.984 & 21.984 & 21.984 \\
\hline 2 & Cropping index & $\%$ & 277 & 0 & 5 \\
\hline 3 & Harvested area & $\mathrm{Ha}$ & 60.896 & 24 & 1.078 \\
\hline 4 & Cropping productivity & $\mathrm{Ton} / \mathrm{Ha}$ & 7 & 8 & 1 \\
\hline 5 & Harvested area & $\mathrm{Ton}$ & 406.174 & 207 & 1.337 \\
\hline 6 & Price & $\mathrm{Rp} / \mathrm{Ton}$ & 4.000 .000 & 3.500 .000 & 7.900 .000 \\
\hline 7 & Production cost & $\mathrm{Rp} / \mathrm{Ha}$ & 14.940 .000 & 11.577 .000 & 8.075 .000 \\
\hline 8 & Total production cost & $\mathrm{Rp}$ & 909.781 .459 .200 & 282.461 .603 & 8.706 .680 .292 \\
\hline 9 & Profit & $\mathrm{Rp}$ & 1.624 .696 .742 .400 & 723.293 .963 & 10.562 .308 .376 \\
\hline 10 & Value of economic benefit & $\mathrm{Rp}$ & 714.915 .283 .200 & 440.832 .361 & 1.855 .628 .085 \\
\hline & Total NME & $\mathrm{Rp} / \mathrm{Ha}$ & 11.740 .000 & 18.068 .000 & 1.721 .000 \\
\hline
\end{tabular}

From the table above, value of economic benefit for agriculture in Delta Brantas Irrigation Area is Rp. 31.529.000,-/Ha. Conversion of Value of economic benefit for per $\mathrm{m}^{3}$ of water use is :

$\mathrm{NME}=\mathrm{NME} /$ (water usage / harvested area)

= Rp. 31.529.000,-/Ha/(473.741.100 $\left.\mathrm{m}^{3} / 61.998 \mathrm{Ha}\right)$ $=$ Rp. $4 \cdot 126,-/ \mathrm{m}^{3}$

Water contribution factor $=$ (basic service fee $\mathrm{x}$ quality of service factor) / production cost

$=\left(\right.$ Rp. $262,-/ \mathrm{m}^{3}$ x 67,66\%) $/$

Rp. $4.126,-/ \mathrm{m}^{3}$

$=3,91 \%$

NME for agriculture water $=$ NME $\mathrm{x}$ water contribution factor

$=$ Rp. $4 \cdot 126,-/ \mathrm{m}^{3} \times 3,91 \%$

$=$ Rp. $161,-/ \mathrm{m}^{3}$

\section{BJPSDA of Irrigation}

By using equation 2 above, BJPSDA of irrigation in Brantas irrigation area can be calculated as follows:

\section{BJPSDA = (basic service fee $\boldsymbol{x}$ quality of service factor) + value of economic benefit} $=\left(\right.$ Rp. $262,-/ \mathrm{m}^{3}$ x 66,67\%) + Rp. 161,-/ $\mathrm{m}^{3}$ $=$ Rp. $338,-/ \mathrm{m}^{3}$

BJPSDA of irrigation unit value for Delta Brantas Irrigation Area is Rp. 338,-/ $\mathrm{m}^{3}$.

\section{BJPSDA of Irrigation Comparative Analysis}

From the analysis in the previous section, the obtained a value of BJPSDA irrigation based on the Regulation of the Ministry of Public Works and Public
Housing No. 18/PRT/ M/2015 amounted to Rp. 255,-/m³, and the value of BJPSDA irrigationbased on the modelling of basic service cost by taking into account service quality factor and NME amounted to Rp. 338,- $/ \mathrm{m}^{3}$.

To obtain clearer understand, the comparison can be seen in the following table :

Table-5. Value Comparison of BJPSDA Irrigation

\begin{tabular}{|c|c|c|c|c|c|c|c|r|}
\hline \multicolumn{4}{|c|}{ Regulation No. 18/PRT/M/2015 } & \multicolumn{4}{c|}{ Basic Service Cost Modelling } \\
\hline $\begin{array}{c}\text { Water Resource } \\
\text { Management Cost }\end{array}$ & NME & \multicolumn{2}{|c|}{ Volume } & BJPSDA & $\begin{array}{c}\text { Basic } \\
\text { Service } \\
\text { Cost }\end{array}$ & $\begin{array}{c}\text { Service } \\
\text { Factor }\end{array}$ & NME & BJPSDA \\
\hline (Rp) & $(\%)$ & $(\mathrm{Ha})$ & $(\mathrm{m} 3)$ & $(\mathrm{Rp} / \mathrm{m} 3)$ & $(\mathrm{Rp} / \mathrm{m} 3)$ & $(\%)$ & $(\mathrm{Rp} / \mathrm{m} 3)$ & $(\mathrm{Rp} / \mathrm{m} 3)$ \\
\hline 1.413 .249 .353 .912 & $62,94 \%$ & 1.078 .589 & 3.492 .648 .792 & 255 & 262 & $67,66 \%$ & 161 & 338 \\
\hline
\end{tabular}

BJPSDA irrigation based on the Regulation of the Ministry of Public Works and Public Housing No. 18/PRT/ M/2015 calculated only based on the water resource management cost. In order to generates BJPSDA irrigation, the water resource management cost based on the real needs are divided propostionally accordingly to the weighting of NME generated respectively for the receiver of benefits of water resources. In this study, a weight of value of economic benefit for agricultural amounted to $62,94 \%$. Then the value of BJPSDA irrigation is amounted to $62,94 \%$ from the real needs of water resource management cost, divided by water usage per hectare of a farm obtaine a value of Rp. $255,-/ \mathrm{m}^{3}$.

The cost structure of BJPSDA based on the Regulation of the Ministry of Public Works and Public Housing No. 18/PRT/ M/2015 is actually only from water resourcer management cost. Percentage of the value of economic benefits is used as the devider for water resources management cost, accordingly to the proportion of its utilization based on the value of benefits obtained. The water resource management cost calculated is only a form of variable cost, with the concept that the fixed cost is the subsidiary provided by the government which have a direct benefit to the water resources conservation ${ }^{[2]}$, such as the construction of dams, ponds, irrigation building, raw water facilities, flushing activities, wastewater management, river bank reinforcement and beach protection structure.

Because the main components that form BJPSDA is only water resource management cost, the concepts used in the calculation of BJPSDA based on the Regulation of the Ministry of Public Works and Public Housing No. 18/PRT/ M/2015 is that BJPSDA used as cost recovery for water resource management cost for operations and maintenance activities.

BJPSDA of irrigation based on the basic service fee by considering the quality of service and value of economic benefits modelling is calculated from basic services fee added by value of economic benefits (NME) amounted Rp. 338,-/ $\mathrm{m}^{3}$. Cost structure that form BJPSDA based on modeling is a basic service costs multiplied by a factor of quality of service and added by NME as a benefit obtained from water users. From the analysis of the calculation, the basic services fee amounted to Rp. 262,$/ \mathrm{m}^{3}$. The cost of basic services will always be fixed for all kinds of water users in a river basin.

Services gained by the water user may be different, thus in order to differenciate any use of water, basic service fee will be affected by quality of service 
factor. Quality of service factor includes conflict conditions, level of service, and water quality ${ }^{[2]}$. Quality of service factor for Delta Brantas Irrigation Area is 67,66\%. Thus the basic service fee for Delta Brantas Irrigation Area which has been adjusted with the service quality factor is Rp. $177,-/ \mathrm{m}^{3}$.

Value of economic benefit is a benefit or advantage derived from the use of water in a river basin. The value of economic benefit will generates a different unit cost depending on the water usage activity, production results and benefits obtained from water utilization. From the calculation, the value of economic benefit agriculture in Delta Brantas Irrigation Area amounted to Rp. $161,-/ \mathrm{m}^{3}$.

In calculation of BJPSDA of irrigation based on the basic service fee by considering the quality of service and value of economic benefits modelling, NME was added to basic service fee which has been adjusted with the service quality factor. This method of BJPSDA calculation is called procentage tariff ${ }^{[2]}$.

According to the concept conveyed by Roger, et al (2002) and Shatanawi (2011) in Sangkawati (2014) $)^{[7]}$ who defines among cost, water value, and water price, where water value is the amount that assessed from the benefits view of beneficiaries, including water benefits value, benefits from returned flows, indirect benefits and intrinsic values. Because the calculation of BJPSDA based on this modelling was adding NME as the benefits obtained by farmers, this method of BJPSDA is actually a water value.

From the results of analysis above, comparison between BJPSDA of irrigation based on the Regulation of the Ministry of Public Works and Public Housing No. 18/PRT/ M/2015 and BJPSDA of irrigation based on the basic service fee by considering the quality of service and value of economic benefits modelling like below :

Table-6. The Comparison of BJPSDA Calculation Method

\begin{tabular}{|c|l|l|l|}
\hline No. & Description & $\begin{array}{l}\text { BJPSDA of Irrigation } \\
\text { Based on Regulation }\end{array}$ & $\begin{array}{c}\text { 年JPSDA of } \\
\text { Irrigation Based on } \\
\text { Modelling }\end{array}$ \\
\hline 1. & Component & $\begin{array}{l}\text { Management cost, \% } \\
\text { NME, volume } \\
\text { (harvested area or the } \\
\text { amount of water usage) }\end{array}$ & $\begin{array}{l}\text { Management costs, } \\
\text { the total water } \\
\text { volume, service } \\
\text { quality factors, } \\
\text { NME }\end{array}$ \\
\cline { 3 - 4 } & & $\begin{array}{l}\text { Not influenced by } \\
\text { quality of service }\end{array}$ & $\begin{array}{l}\text { Influenced by } \\
\text { quality of service }\end{array}$ \\
\cline { 3 - 5 } & $\begin{array}{l}\text { NME used as devider of } \\
\text { water resources } \\
\text { management cost } \\
\text { proportionaly }\end{array}$ & $\begin{array}{l}\text { NME added as } \\
\text { benefits obtained by } \\
\text { water users }\end{array}$ \\
\hline 2. & Type & $\begin{array}{l}\text { Subsidized cost pricing } \\
\text { at fixed cost }\end{array}$ & Procentage tarif \\
\hline 3. & Nature & Cost recovery & Water value \\
\hline
\end{tabular}

\section{CONCLUSIONS}

Based on the results of this study the following conclusions are drawn :

1. BJPSDA of irrigation value in Delta Brantas Irrigation Area based on the Regulation of the Minister of Public
Works and Public Housing No. 18/PRT/M/2015 is Rp. $255,-/ \mathrm{m}^{3}$, as a cost recovery.

2. BJPSDA of irrigation value in Delta Brantas Irrigation Area based on basic service fee by considering the quality of service and value of economic benefits modelling is Rp. $338,-/ \mathrm{m}^{3}$, consists of basic service fee as fixed costs Rp. 177,-/ $\mathrm{m}^{3}$, and NME for agriculture water Rp. $161,-/ \mathrm{m}^{3}$, as a water value.

3. BJPSDA cof irrigation alculation based on the Regulation of the Minister of Public Works and Public Housing No. 18/PRT/M/2015, NME value is used as devider on the total cost of Water Resources Management Costs. While BJPSDA based on basic service fee by considering the quality of service and value of economic benefits modelling, NME value calculated as an addition for BJPSDA on profit that farmers gains.

\section{REFERENCES}

[1] Ministry of Public Works and Public Housing. 2015. Regulation of The Minister of Public Works and Public Housing No. 18/PRT/M/2015 about Exploitation Fees and Irrigation Structure Maintenance. Secretary of Ministry of Public Works and Public Housing, Jakarta.

[2] Anwar, N and Utomo, C. 2013. Final Report Individual Consultants Experts Water Resource Management (Concept, Calculation, Simulation) Water Resource Management Service Costs (BJPSDA) Calculation. Surabaya

[3] Ministry of Public Works and Public Housing. 2015. Regulation of The Minister of Public Works and Public Housing No. 30/PRT/M/2015 about Development and Management of Irrigation System. Secretary of Ministry of Public Works and Public Housing, Jakarta.

[4] Government of Republic Indonesia. 1974. Enactment No. 11/1974 about Irrigation. Ministry of Law and Human Right, Jakarta

[5] Mulyadi. 2005. Financial Management. Erlangga Publisher, Jakarta.

[6] Sarwan, S., Rachmadi, E., and Mardiyono, A. 2012. BJPSDA Calculation (BJPSDA Training). Directorate of Water Resource Management Development, Bandung.

[7] Sangkawati, S. 2014. Public Opinion Study for budgetting, Operation, Maintenance, and Water Resource Management. Civil Engineering Journal Diponegoro University. 129-138. 